\title{
Lightweight males of Podisus nigrispinus (Heteroptera: Pentatomidae) neglect lightweight females due low reproductive fitness
}

\author{
A. I. A. Pereira ${ }^{a *}$, R. B. Silva ${ }^{b}$, W. S. Tavares, J. B. Malaquias ${ }^{d}$ and J. C. Zanuncio ${ }^{e}$ \\ anstituto Federal Goiano, Campus Urutaí, Rodovia Geraldo Silva Nascimento, Fazenda Palmital, \\ CEP 75790-000, Urutaí, GO, Brazil \\ ${ }^{b}$ Departamento de Entomologia, Embrapa Milho e Sorgo, Rodovia MG 424, Km 65, \\ CEP 35701-970, Sete Lagoas, MG, Brazil \\ 'Departamento de Fitotecnia, Universidade Federal de Viçosa - UFV, Avenida PH Holfs, Centro, \\ CEP 36570-000, Viçosa, MG, Brazil \\ ¿Departamento de Entomologia e Acarologia Agrícola, Escola Superior de Agricultura “Luiz de Queiroz", \\ Universidade de São Paulo - USP, Avenida Pádua Dias, 11, CEP 13418-900, Piracicaba, SP, Brazil \\ 'Departamento de Biologia Animal, Universidade Federal de Viçosa - UFV, Campus Universitário, \\ CEP 36570-000, Viçosa, MG, Brazil \\ *e-mail: aiapereira@yahoo.com.br
}

Received: July 30, 2015 - Accepted: January 14, 2016 - Distributed: May 31, 2017

(With 6 figures)

\begin{abstract}
Sexual choice by male stink bugs is important because females that experience food shortages lay fewer eggs with lower viability compared with well-fed females. In this study, we investigated whether Podisus nigrispinus (Dallas) (Heteroptera: Pentatomidae) males fed with a low-quality diet during its nymphal stage show selectivity for sexual partners resulting in high-quality progeny. Lightweight males and females were obtained from nymphs fed weekly with Tenebrio molitor L. (Coleoptera: Tenebrionidae) pupae. By contrast, heavyweight males and females were fed three times a week and received an extra nutritional source: cotton leaves, Gossypium hirsutum L. (Malvaceae). Lightweight males preferred to mate with heavy females $(77.78 \pm 14.69 \%)$, whereas heavyweight males did not discriminated between light or heavyweight females. Females mated with lightweight males showed similar levels of reproduction to those mated with heavyweight males. The results provide an indication of the importance of male and female body weight for sexual selection in Asopinae stink bugs.
\end{abstract}

Keywords: body weight, reproductive success, stink bug, predation, sexual selection.

\section{Machos leves de Podisus nigrispinus (Heteroptera: Pentatomidae) negligenciam fêmeas leves devido ao baixo desempenho reprodutivo}

\begin{abstract}
Resumo
A seleção sexual por machos de percevejos é importante porque fêmeas que passaram por escassez alimentar poem poucos ovos com baixa viabilidade em comparação com fêmeas bem alimentadas. Nesse estudo, investigamos se machos de Podisus nigrispinus (Dallas) (Heteroptera: Pentatomidae) alimentados com dieta de baixa qualidade durante seu estágio ninfal apresenta seletividade por parceiras sexuais resultando em progênie de alta qualidade. Machos e fêmeas leves foram obtidos de ninfas alimentadas semanalmente com pupas de Tenebrio molitor L. (Coleoptera: Tenebrionidae). Em contraste, machos e fêmeas pesados foram alimentados três vezes por semana e receberam uma fonte nutricional extra: folhas de algodão, Gossypium hirsutum L. (Malvaceae). Machos leves preferiram acasalar com fêmeas pesadas $(77,78 \pm 14,69 \%)$, enquanto machos pesados não distinguiram fêmeas leves ou pesadas para acasalamento. Fêmeas que acasalaram com machos leves apresentaram níveis de reprodução semelhantes em comparação com aquelas acasaladas com machos pesados. Os resultados fornecem uma indicação da importância do peso corpóreo de machos e fêmeas para a seleção sexual em percevejos Asopinae.
\end{abstract}

Palavras-chave: peso corpóreo, sucesso reprodutivo, percevejo, predação, seleção sexual. 


\section{Introduction}

Stink bugs of the genus Podisus (Heteroptera: Pentatomidae: Asopinae) can reduce population levels of defoliating Lepidoptera in agricultural and forested areas. Podisus spp. are considered to be important biological control agents, particularly in Brazil (Zanuncio et al., 2002a). Over the past two decades, research has focused on rearing and release technologies with these insects for using (Jusselino-Filho et al., 2003; Lacerda et al., 2004; Torres et al., 2006).

Asopinae stink bugs, such as Podisus maculiventris (Say) (Heteroptera: Pentatomidae), are unable to control immediately pests that have an unsynchronized population increase over a short timescale, which is often the case in monocultures (O'Neil et al., 1996). The population growth of stink bugs and other such agents is partly dependent on various reproductive processes, such as sexual selection, which are poorly studied in many Neotropical insects (Zunic et al., 2008).

The searching, locating and mating behaviors in stink bugs rely on physical and chemical stimuli, such as attraction to volatiles released by injured plants (Dickens, 1999). Methodological difficulties, high cost of laboratory procedures, complexity of chemical ecology and lack of field studies contribute to gaps in current knowledge of the reproductive ecology of asopinid stink bugs. Semiochemicals have been identified for less than $1 \%$ of the 38,000 species of Heteroptera (Moraes et al., 2008). Therefore, studies about sexual selection behavior of these insects would be go some way to answering questions about their reproductive ecology.

The parental investment theory predicts that females of species whose males invest heavily in the fitness of their offspring will compete for resources and/or sexually active males, but they can be selective in their choice of partner (Bonduriansky, 2001). The processes involved in sexual selection by Podisus nigrispinus (Dallas) (Heteroptera: Pentatomidae), an important Neotropical predator, are poorly studied. However, there is a need to develop methodologies to maximize its reproduction and adaptability in the field.

Polyandrous males can win intrasexual competition either externally (e.g. efficiency in courtship) or within their partner (e.g. sperm competition) (Franco et al., 2011). Copulation duration is likely to be one of the most effective mechanisms in stink bugs, although competition among sperm resulting from lengthy copulation is poorly studied in these insects (Lundgren, 2011). Copulation by Nezara viridula (L.) (Heteroptera: Pentatomidae) was longer in the presence of more than one male (McLain, 1980). Longer copulations by $P$. nigrispinus were attributed to the protracted movement of the aedeagus to reach the spermatheca and release the sperm, rather than the length of copulation acting as a guarding behavior (Rodrigues et al., 2008). However, the production of polymorphic sexual cells by P. nigrispinus males suggests that there are distinct functions to these cells and indicates the evolutionary importance of intrasexual competition (Araújo et al., 2011).

Podisus nigrispinus adults might face sexual competition, but the set of selection criteria for partners by this predator are unknown. In this study, we investigated the hypothesis that males of $P$. nigrispinus, reared on a low-quality diet during their immature stages (lightweight males), prefer sexual partners fed on a high-quality diet with the aim to achieve greater reproductive fitness.

\section{Material and Methods}

\subsection{Rearing conditions of Podisus nigrispinus}

The research was conducted in a greenhouse at the Department of Animal Biology and at the Laboratory of Biological Control of Insects (LBCI) in the Institute of Biotechnology Applied to Agriculture (BIOAGRO) of the Federal University of Viçosa (UFV) in Viçosa, Minas Gerais state, Brazil. Specimens of P. nigrispinus were obtained from colonies at the LBCI, where they are reared in screened wood cages $(30 \times 30 \times 30 \mathrm{~cm})$ with water and Eucalyptus urophylla leaves (Myrtaceae) as a substrate for supplementary feeding. The colonies are supplemented with Tenebrio molitor L. (Coleoptera: Tenebrionidae) pupae placed on the upper outer part of the cages (Zanuncio et al., 2001).

\subsection{Experiment 1: Choice tests and elaboration of ethograms}

Body weight enables males and females of $P$. nigrispinus to be differentiating on the basis of whether they were fed with a complete or incomplete diet (Scriber and Slansky Junior, 1981). In the greenhouse, second instar nymphs of $P$. nigrispinus $(n=300)$ were kept in organza bags $(25 \times 15 \mathrm{~cm})$ and reared with two different diets (D); D1: based on zoophagy through only T. molitor pupae or D2: based on zoophytophagy through $T$. molitor pupae and cotton leaves, Gossypium hirsutum L. (Malvaceae). Lightweight females and males were those reared on the D1 diet, whereas heavyweight females and males were reared on the D2 diet. D1 represented a nutritionally incomplete diet (De Clercq and Degheele, 1992), whereas D2 represents a nutritionally complete diet according to Lemos et al. (2003).

Ten P. nigrispinus nymphs were kept per organza bag (representing one experimental unit) with 15 replications per diet. For each replication, a plastic dental anesthetic tube $(2.5 \mathrm{~mL})$ containing distilled water was placed on the top of each bag to provide moisture (Zanuncio et al., 2004).

For each group of ten nymphs of $P$. nigrispinus on the D1 diet, two T. molitor pupae were provided once every seven days. The T. molitor pupae were left in the bag until the seventh day (even if they were partially predated or not) to avoid cannibalism (Pires et al., 2011). In the D2 set-up, 25-day-old cotton plants were kept in plastic vases $(54 \times 34 \mathrm{~cm})$ with adequate moisture and fertilizer. Bags containing P. nigrispinus nymphs were arranged so that they included branches of the cotton plant containing healthy 
leaves. For each replication, the bag was removed from the plant once the last adult had emerged. Two T. molitor pupae were provided for each group of ten nymphs and replaced every two days.

Recently molted $P$. nigrispinus adults were sexed, soon after emergence, based on the external appearance of their genitalia (Zanuncio et al., 2002b), weighed and individualized in Petri dishes $(9.0 \times 1.5 \mathrm{~cm})$ with a piece of cotton soaked in distilled water fixed inside the cover plate to provide water and moisture. Males and females of P. nigrispinus, regardless of diet, were individualized for 4 days in BOD climate chambers at $25 \pm 2{ }^{\circ} \mathrm{C}, 60 \pm 10 \% \mathrm{RH}$ and a 12:12 (L:D) photoperiod until they reached sexual maturation (Zanuncio et al., 1992). For these four days, the adults were fed on the same diet to which they had been experienced as nymphs. After this period, the sexually mature adults were kept in plastic trays $(40 \times 40 \times 20 \mathrm{~cm})$ capped with a piece of a $2 \times 2 \mathrm{~mm}$ mesh plastic screen with dimensions of $50 \times 50 \mathrm{~cm}$ to prevent leakage and to facilitate visualization of adults behavior. This cap was placed over the plastic tray and its edges were folded and secured to the side plate with elastic alloy. Healthy adults (without broken legs or antennae) were used in the mating choice tests with two treatments: (T1) one lightweight male with one light- and one heavyweight female; and (T2) one heavyweight male with one light- and one heavyweight female (Figure 1). The adults were differentiated between treatments with a patch of odorless water-based white paint on the back tibia of lightweight adults. This paint not had been shown to influence mating behavior in previous trials (AIAP, personal observations).
The choice tests were assembled from 10:00 am because $P$. nigrispinus is known to have a higher mating frequency near midday (Pires et al., 2006). Females were placed at the end and males in the middle of the tray (Figure 1) with 30 replications, each with a tray with two different females and one male. The cap (plastic screen) was mounted on the edges of the pan; the mating behavior was evaluated immediately after adult introduction using an ethogram model developed by Carvalho et al. (1995).

The pre-copulation period of $P$. nigrispinus ranged from $59.28 \pm 15.22$ to $90.42 \pm 20.42$ min (preliminary observations for ten pairs). Thus, the maximum period of choice tests was either four hours or as long as was required for the male to insert its aedeagus into one of the two females, perform a $180^{\circ}$ turn and move in the opposite direction of its chosen partner. These steps following copulation are known to be characteristic of asopinid stink bugs (Tostowaryk, 1971). Couples that did not mate after four hours from the beginning of the observations were recorded as unmated. Data relating to the total number of matings, the choice made by the males and which sex took initiative were recorded for both treatments.

For the elaboration of the ethograms, 40 newly emerged couples from the two diets (D1 or D2) were kept in circular arenas $(14.0 \times 2.0 \mathrm{~cm})$ and the courtship behavior and mating described without interruption according to the methodology described by Carvalho et al. (1995). The length of time (min) taken for specific stages of P. nigrispinus mating behavior was compared.

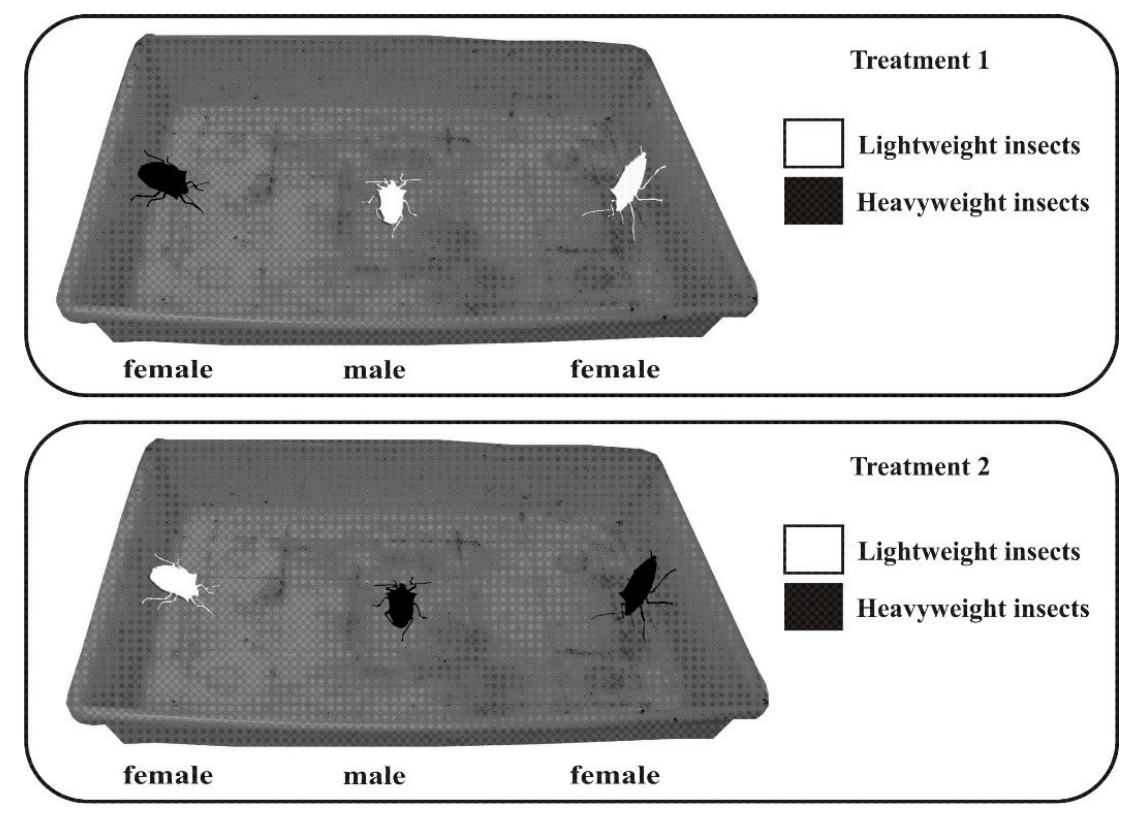

Figure 1. Arena of the choice test for Podisus nigrispinus (Heteroptera: Pentatomidae) adults. Treatment 1: a light- and heavyweight female and a lightweight male and Treatment 2: a light- and heavyweight female and a heavyweight male. Lightweight females and males had a diet under their nymphal stage based on zoophagy with only Tenebrio molitor L. (Coleoptera: Tenebrionidae) pupae whereas heavyweight females and males had a diet based on zoophytophagy through T. molitor pupae and cotton, Gossypium hirsutum L. (Malvaceae), leaves. 


\subsection{Experiment 2: Fertility and fecundity depending on the choice}

Adults of P. nigrispinus from the two diets (D1 and D2) were sexed, weighed and placed individually in Petri dishes $(9.0 \times 1.5 \mathrm{~cm})$ for five days inside BOD chambers at $25 \pm 2{ }^{\circ} \mathrm{C}, 60 \pm 10 \% \mathrm{RH}$ and a $12: 12$ (L:D) photoperiod. Twenty pairs were used per treatment: T1, heavyweight male paired with a heavyweight female; T2, heavyweight male paired with a lightweight female; T3, lightweight male paired with a heavyweight female and T4, lightweight male paired with a lightweight female.

The pairs were kept in Petri dishes $(12 \times 2 \mathrm{~cm})$ with a piece of cotton dipped in distilled water to provide moisture. Pupae of T. molitor were offered ad libitum per pair and, every $24 \mathrm{~h}$, the oviposition period, number of eggs, eggs per female, incubation period, egg viability and number of nymphs originated after egg hatching were recorded.

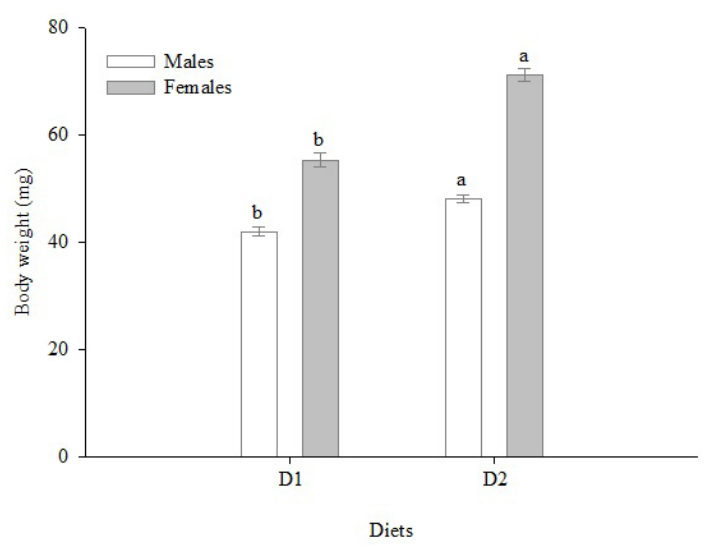

Figure 2. Body weight (Mean $\pm \mathrm{SE}$ ) of Podisus nigrispinus (Heteroptera: Pentatomidae) males and females fed with Tenebrio molitor L. (Coleoptera: Tenebrinidae) pupae every seven days (D1) or with $T$. molitor pupae every two days and cotton (Gossypium hirsutum L.) (Malvaceae) leaves (D2). Means, for each sex, followed by the same letter do not differ by the Tukey test $(\mathrm{P}>0.05)$.

\subsection{Statistics}

All data were submitted to the assumption of normality with the Lilliefors's adhesion test and visually by the symmetry of the histogram provided by the SAEG software version 9.1 (Ribeiro Junior and Melo, 2008). Data concerning weight of the males and females from both diets followed a normal distribution and, thus, they were analyzed through a simple analysis of variance (ANOVA) and compared by the F test; results were significant if $P<0.05 \%$. Data concerning number of matings and choice test showed a non-normal distribution and, therefore, were analyzed with the nonparametric test for two samples Wilcoxon-Mann-Whitney test $(P<0.05)$. The time taken for $P$. nigrispinus males performing certain steps of the ethogram and the data from Experiment 2 followed normal distribution and, therefore, they were analyzed with ANOVA and the means compared by the Tukey's test $(P<0.05)$.

\section{Results}

Males $(\mathrm{F}=30.93, P=0.002)$ and females $(\mathrm{F}=79.25$, $P<0.001)$ of $P$. nigrispinus that were fed by zoophytophagous D2 diet were heavier than those fed the zoophagous D1 diet (Figure 2). Individuals in the choice test representing T1 mated in $70.00 \pm 8.50 \%$ of cases $(Z=5.64, P=0.001)$, whereas in the T2 set-up, $60.61 \pm 8.50 \%(\mathrm{Z}=2.96, P=0.001)$ (Figure 3A). Males and females of $P$. nigrispinus moved randomly without a behaviorally defined sequence and with periods of immobility, regardless of diet, soon after entering the arena.

The choice of females by males of $P$. nigrispinus differed according to the type of diet in the immature stage. Lightweight males preferred heavyweight $(77.78 \pm 14.69 \%)$ over lightweight females $(22.22 \pm 14.69 \%)(\mathrm{Z}=7.75, P=0.001)$, whereas heavyweight males (fed a zoophytophagous D2 diet) did not discriminate between heavy- $(54.54 \pm 15.74 \%)$ or lightweight (45.45 $\pm 15.74 \%)(\mathrm{Z}=1.26, P=0.102)$ females (Figure 3B).

The initiation for mating was similar between light-versus heavyweight males $(\mathrm{F}=0.624, P>0.05)$ (Figure $4 \mathrm{~A})$ and
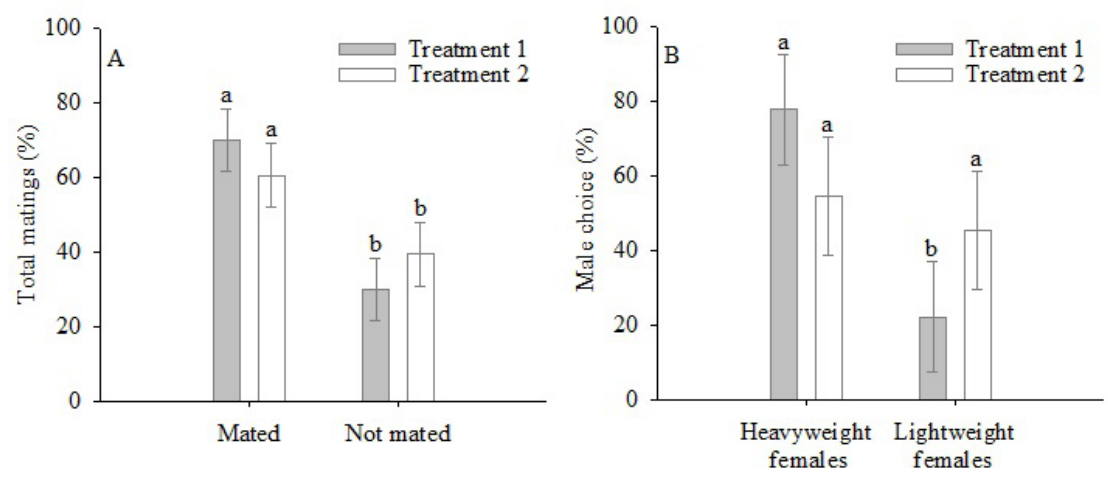

Figure 3. Podisus nigrispinus (Heteroptera: Pentatomidae) total matings (A) and male choice (B) on the choice test in Treatment T1: a light- and heavyweight female and a lightweight male and Treatment T2: a light- and heavyweight female and a heavyweight male. Means followed by the same letter do not differ by the Wilcoxon-Mann-Whitney test $(\mathrm{P}>0.05)$. 
between treatments $(\mathrm{F}=0.748, P>0.05)$ (Figure 4B). However, heavyweight females initiated more matings with light- (T1) and heavyweight (T2) males compared with lightweight females ( $\mathrm{F}=25.02, P=0.01)$ (Figure 4C).

The steps in mating behavior of $P$. nigrispinus adults were similar for both heavy- and lightweight males and
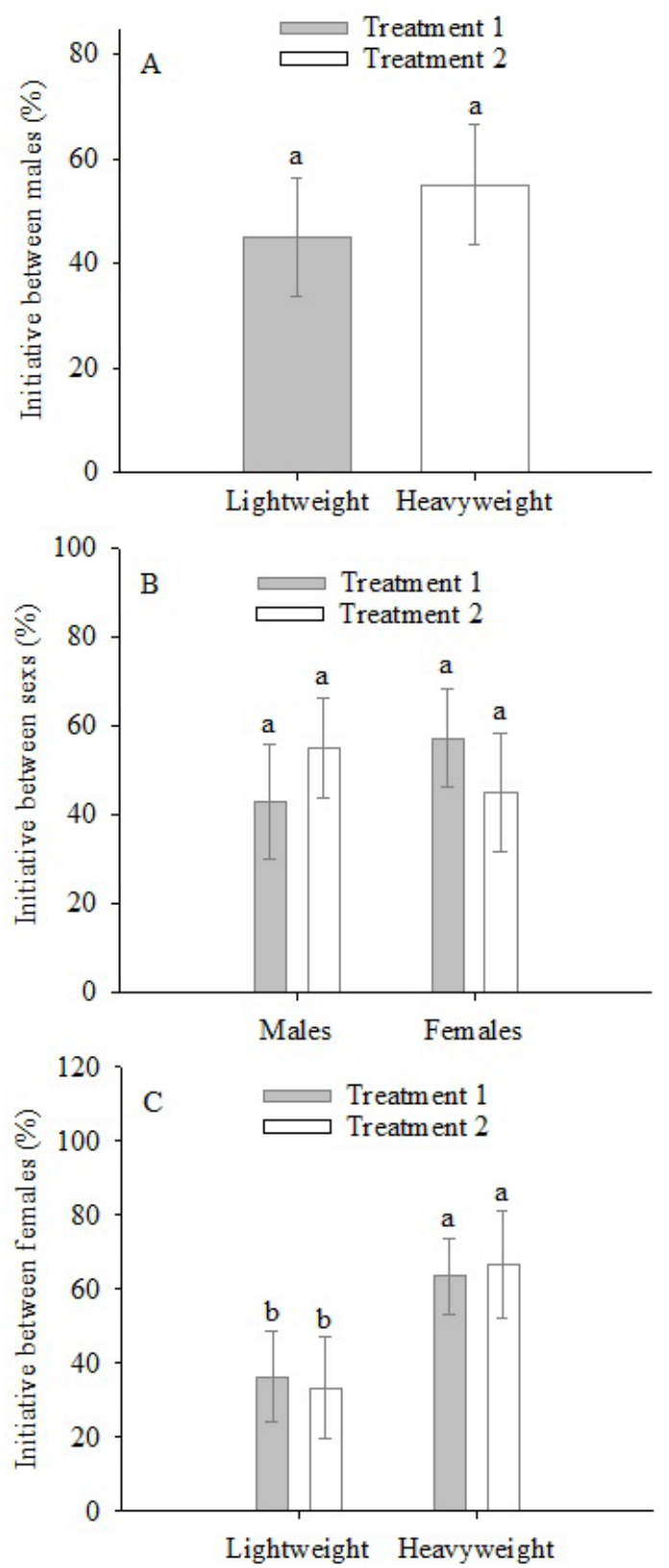

Figure 4. Podisus nigrispinus (Heteroptera: Pentatomidae) male mating behavior and sexual choice on the choice test for the Treatment T1 (a light- and heavyweight female and a lightweight male) and Treatment T2 (a light- and heavyweight female and a heavyweight male). Means followed by the same letter do not differ by the Wilcoxon-Mann-Whitney $(\mathrm{P}>0.05)$. females and, therefore, only one descriptive ethogram of P. nigrispinus mating behavior is presented (Figure 5). Podisus nigrispinus males touched the back of the females with their antennae, positioning them in a $\mathrm{V}$ shape for copulation, whereas females positioned their antennas in an inverted V shape. Males climbed onto the back of the females from either their anterior, posterior or lateral end, positioning their head in the same direction of the female. The male, immediately after this, rotated $180^{\circ}$ on the female, touched the rear of her abdomen with his antennae and then repositioned himself so that his head was in the same direction as that of the female (Figure 5). The females remained motionless and males tried to initiate copulation. In ten replications, females rejected the males with their hind legs or inclined their abdomen upwards, preventing copulation (Figure 5).

The period between the start of the experiment to the point at which the males located the females (6-7 $\mathrm{min})$ $(\mathrm{F}=0.408, P=0.10)$ and between the male mounting the female and its completed $180^{\circ}$ spin $(\mathrm{F}=0.528, P=0.06)$ (Figure 6A and $\mathrm{C}$ ) were similar among treatments. However, the duration between locating and then mounting the female differed between treatments $(\mathrm{F}=22.34, P=0.001)$ (Figure 6B).

The number of eggs per lightweight female mated with a lightweight male was $37.12 \%$ less than those produced by heavyweight ones $(\mathrm{F}=36.75, P=0.003)$ (Table 1$)$. Moreover, heavyweight females produced more eggs $(32.66 \%)$ than did lightweight females mated with heavyweight males. The number of nymphs per female $(\mathrm{F}=28.66, P=0.00)$ and egg viability $(\mathrm{F}=42.31, P=0.05)$ were also lower for lightweight than for heavyweight females, independent

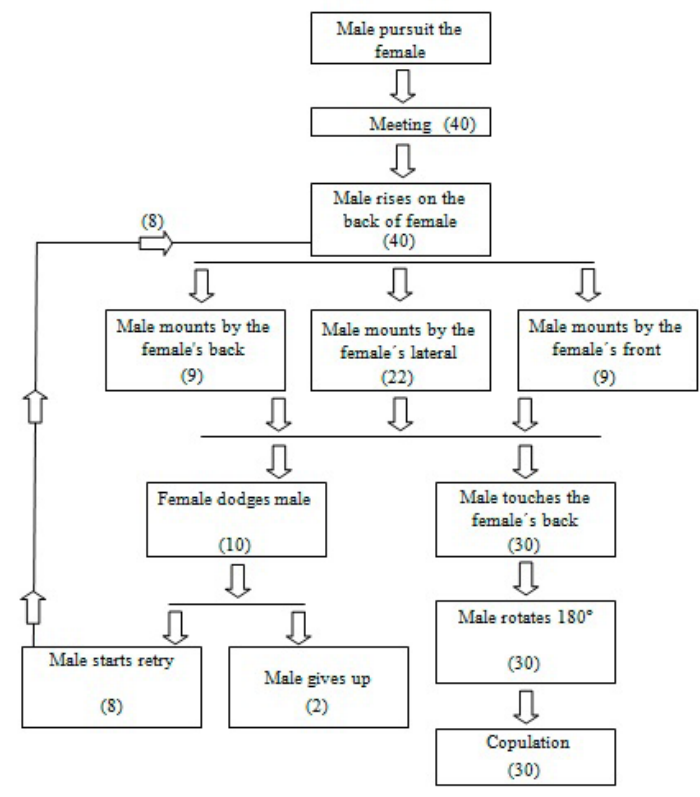

Figure 5. Courtship and mating ethogram for Podisus nigrispinus (Heteroptera: Pentatomidae) with the frequency (number in parenthesis) of insects that performed each behavioral step. 

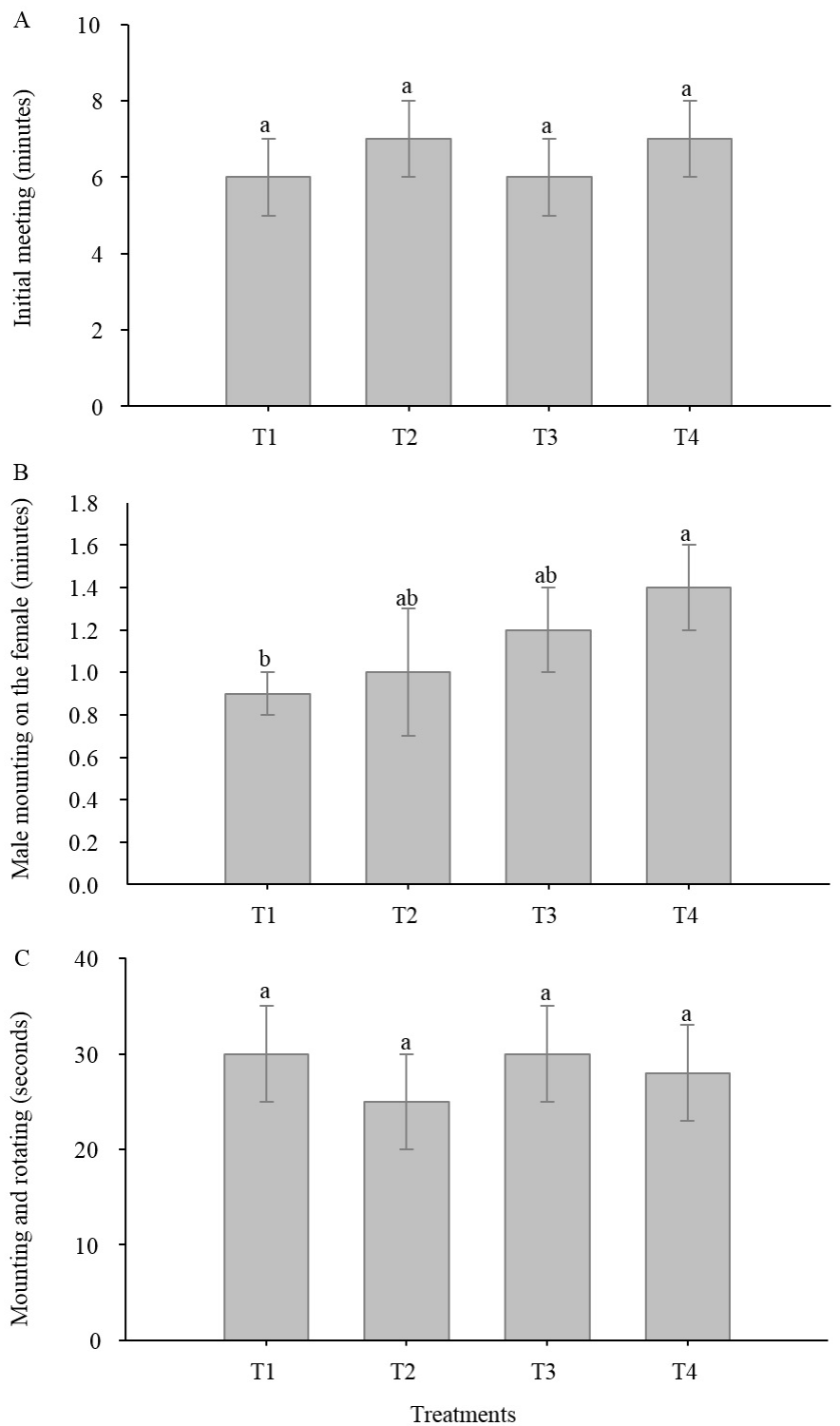

Figure 6. Time (Mean $\pm \mathrm{SE}$ ) for Podisus nigrispinus (Heteroptera: Pentatomidae) males performing certain stages of the mating ethogram according to the treatments: T1 (heavyweight male and female), T2 (heavyweight male and lightweight female), T3 (lightweight male and heavyweight female) and T4 (lightweight male and female). (A) Time interval between the beginning of the experiment and the meeting of the male with the female; (B) Time interval spent by the male for meeting and mount the female; and (C) Time interval spent by the male for mounting and perform a $180^{\circ}$ turn. Means followed by the same letter do not differ by the Tukey test $(P>0.05)$.

Table 1. Number of eggs and nymphs per female, incubation period (days) and egg viability (\%) (Mean $\pm \mathrm{SE}^{1}$ ) of Podisus nigrispinus (Heteroptera: Pentatomidae) females according the treatments: T1 (heavyweight male and female), T2 (heavyweight male and lightweight female), T3 (lightweight male and heavyweight female) and T4 (lightweight male and female) under $25 \pm 2{ }^{\circ} \mathrm{C}, 60 \pm 10 \%$ RH and 12:12 (L:D) photoperiod.

\begin{tabular}{ccccc}
\hline & Eggs/female & Nymphs/female & Incubation period (days) & Egg viability (\%) \\
\hline T1 & $628.67 \pm 33.41 \mathrm{a}$ & $532.21 \pm 46.78 \mathrm{a}$ & $5.91 \pm 0.23 \mathrm{a}$ & $84.66 \pm 2.61 \mathrm{a}$ \\
T2 & $423.32 \pm 25.09 \mathrm{~b}$ & $246.57 \pm 32.21 \mathrm{~b}$ & $5.57 \pm 0.21 \mathrm{a}$ & $58.24 \pm 4.02 \mathrm{c}$ \\
T3 & $651.12 \pm 22.38 \mathrm{a}$ & $491.89 \pm 21.22 \mathrm{a}$ & $5.56 \pm 0.13 \mathrm{a}$ & $75.54 \pm 2.88 \mathrm{~b}$ \\
T4 & $409.40 \pm 31.38 \mathrm{~b}$ & $229.65 \pm 43.56 \mathrm{~b}$ & $5.51 \pm 0.21 \mathrm{a}$ & $56.09 \pm 2.01 \mathrm{c}$ \\
\hline
\end{tabular}

${ }^{1}$ Means followed by the same letter, in each column, do not differ by Tukey test $(P>0.05)$. 
of male type. The egg incubation period did not differ between treatments $(\mathrm{F}=0.02, P>0.05)$ (Table 1$)$.

\section{Discussion}

The weight of adults with the D2 diet was similar to that reported for nymphs of $P$. nigrispinus fed with an adequate diet (daily T. molitor larvae) (Lemos et al., 2003), suggesting that the weekly feeding interval does not limit the ability of this insect to obtaining sufficient nutrients. Tenebrio molitor pupae do not resist manipulation, which reduces the energy costs for predatory nymphs. Furthermore, P. nigrispinus used in the experiment were obtained from a rearing system maintained with successive generations fed with an adequate quantity and quality of food, enabling adults from D1 to reach similar body weights to those recorded from the D2 diet (Mohaghegh et al., 1999). Changes in the diet of predatory stink bugs maintained in laboratory might not have immediate short-term effects (Coudron et al., 2011). Even with the presumably low effect of the feeding interval, the plant material in the diet enabled the adults fed the D2 diet to reach a higher body weight than those fed the D1 diet in a short rearing period.

Podisus nigrispinus adults did not mate in $30 \%(n=9)$ and $40 \%(n=12)$ in the $\mathrm{T} 1$ and $\mathrm{T} 2$ experiments, respectively. This might be because of the sexual maturation of the adults (Zanuncio et al., 1992) and to the time of the day at which the experiments were carried out (Pires et al., 2006). Moreover, the mating period allowed was four hours, which is longer than that observed in other studies. The lack of mating in P. nigrispinus was identified by several movements without a defined behavioral sequence and by periods of immobility, both of which have been previously reported for both sexes in other species of Asopinae before either copulation (Carvalho et al., 1995) or predation (Lemos et al., 2005a).

The selection of heavyweight females by lightweight P. nigrispinus males could boost their fitness by reducing both the risks involved in searching for mates and the energy expended in the production of cells for reproduction, besides the synthesis and transfer of substances to the females (Franco et al., 2011). This strategy can reduce copulations with malnourished females that have lower reproductive capacity (Lundgren, 2011).

The lack of preference by heavyweight males for either heavy- or lightweight females is in disagreement with that observed previously for N. viridula and Euschistus conspersus Uhler (Heteroptera: Pentatomidae). Males of these insects preferred heavier females because of intrasexual competition and the relation between female body size and fecundity (McLain, 1980; Krupke et al., 2008, respectively), as also reported for other Asopinae (Lemos et al., 2009). The mating choice is mediated by risks and benefits and as the risks increase the more careful the searching process for sexual partners becomes (Bonduriansky, 2001). Thus, the lack of rigor in the choices made by heavyweight males in this study suggests that little risk was required when making their choices. The lack of competition and the intermediate body weights of females (mainly for the lightweight females) could explain the lack of choice by heavyweight males. This agrees with the fact that Cyrtodiopsis dalmanni (Wiedemann) (Diptera: Diopsidae) males of large or intermediate sizes made similar choices of females (Hingle et al., 2001).

The lack of competition for mating between P. nigrispinus males and the short distance between the partners could explain the similar number of mating initiations between males fed the different diets. However, over longer distances, pentatomids of one or both sexes can incur costs associated with the synthesis and maintenance of pheromone glands to approach the opposite sex (Aldrich, 1988). The initiative taken for mating can induce behavioral responses, such as the faster approach of one sex to the other as observed in Megacopta punctissimum (Montandon) (Heteroptera: Plataspidae), Jadera haematoloma Herrich-Schaeffer (Heteroptera: Rhopalidae) and Acrosternum hilare (Say) (Heteroptera: Pentatomidae) (Hibino, 1986; Carroll and Salamon, 1995; Capone, 1995, respectively) or in other orders of insects (Crespi, 1989).

The initiation of mating by heavyweight $P$. nigrispinus females over short distances and induction to court by the opposite sex shows a behavioral response to dietary conditions that enable the female to provide adequate maturation of oocytes and ovarian development, as observed for P. maculiventris (Shapiro et al., 2000) and B. tabidus (Lemos et al., 2005b). Asopinid females without plant material in their diet had a longer pre-oviposition period, clutch interval and oviposition period (Adams, 2000; Ramalho et al., 2008; Holtz et al., 2011; Lundgren, 2011), suggesting that lightweight $P$. nigrispinus females were not still ready for mating because of their nutritional status.

The mating behavior showed by $P$. nigrispinus adults confirm that there is a pattern to courtship in Asopinae that does not depend on the type of diet experienced during the immature stages (Carvalho et al., 1995). However, the resistance by lightweight females to mounting by lightweight males suggests that the quality of the partner at the end of courtship behavior (i.e. final acceptance by the female) is important for mating, as found for other insects (Aluja et al., 2008) and spiders (Schäfer et al., 2008).

The longer acceptance period (i.e. until mounting by the male) by females mating with lightweight $P$. nigrispinus males suggests that these females were not receptive, probably because of the reproductive costs associated with steps before oogenesis. Lightweight females can hinder mating to avoid such costs and to await better conditions to obtain energy for reproduction. Trade-offs in asopinid females include increased longevity at the expense of reproduction when inadequate nutritional conditions were observed (Legaspi et al., 1996; Shapiro and Legaspi, 2006; Ramalho et al., 2008). In P. maculiventris, this enabled females from nymphs fed a lower quality diet to recover and show adequate reproduction effort once fed an adequate diet (Legaspi and Legaspi Junior, 2004).

The lack of mating initiations by lightweight females of $P$. nigrispinus can also avoid risks such as horizontal 
transmission of pathogens and predation. This is important for Podisus stink bugs, which can copulate for up to 11 hours (Rodrigues et al., 2009) and assume a mating position that might increase their chances of being predated.

The number of eggs laid by D2 diet P. nigrispinus females, regardless of male quality, was similar to the number laid when the same predator was fed with Alabama argillacea (Hübner) (Lepidoptera: Noctuidae) (its natural prey in Brazil) (Santos and Boiça Junior, 2002), confirming the quality of T. molitor as prey (Torres et al., 2006; Zanuncio et al., 2011). By contrast, the fewer eggs and offspring from D1 fed females, suggests that the diet during immature stage can compromise female reproductive potential (Lundgren, 2011).

The similar reproductive effort of light- and heavyweight P. nigrispinus males with heavyweight females demonstrates that female phenotypic traits (such as body weight) are important for male reproductive success. Heavyweight females of several other insect groups are also preferred for mating (Crespi, 1989).

The similar egg incubation period of $P$. nigrispinus with different combinations of light- or heavyweight females and males indicates that variations are due genetic factors that might be expressed, for example, by the number of eggs laid (Mohaghegh et al., 1998). The egg incubation period for the Asopinae was also similar with different diets (Zanuncio et al., 2012) or when parents were exposed to xenobiotics (Pereira et al., 2009). By contrast, the lower egg viability in T2 and T4 indicates that this parameter depends on the maternal nutritional quality, as observed for B. tabidus (Oliveira et al., 2005), N. viridula and Euschistus heros (Fabricius) (Heteroptera: Pentatomidae) (Fortes et al., 2006). This reinforces the idea that $P$. nigrispinus males can identify true reproductive clues from well-nourished females.

The production of polymorphic sexual cells by P. nigrispinus males might have distinct functions, such as fertilization, nutrition and competition (Araújo et al., 2011). This indicates that the embryos might have components used for parental nutrition (for example) and for maintaining high viabilities. In support of this, virgin females of P. nigrispinus lay infertile eggs (De Clercq et al., 1998) and, in other insects, male quality influences the success of the offspring (Aluja et al., 2008).

The sexual choice of $P$. nigrispinus males contributes to the successful reproduction of this insect, with body weight being an important way to assess the quality of mating partners. Lightweight males distinguished well or poorly fed females using weight as a clue to acquire reproductive success. So, this study may contribute to current understanding of the participation of males in reproduction and suggests that sexual selection by $P$. nigrispinus males depends on female nutritional status. Sexual choice in this and other pentatomid species might be more important than is currently thought, making it necessary to consider the role of male choice in the mating system and sexual selection of this important biological control agent.

\section{Acknowledgements}

To Ancidériton Antônio de Castro, Priscilla Lara Faria and Rita Cristina Pereira de Freitas for helping with the ethogram analysis. To "National Counsel of Technological and Scientific Development (CNPq)", "Foundation for Research Support of the State of Minas Gerais (FAPEMIG)" and "Brazilian Federal Agency for Support and Evaluation of Graduate Education (CAPES)" for financial support. Asia Science corrected and edited the English of this manuscript.

\section{References}

ADAMS, T.S., 2000. Effect of diet and mating on oviposition in the twospotted stink bug Perillus bioculatus (F.) (Heteroptera: Pentatomidae). Annals of the Entomological Society of America, vol. 93, no. 6, pp. 1288-1293. http://dx.doi.org/10.1603/00138746(2000)093[1288:EODAMO]2.0.CO;2.

ALDRICH, J.R., 1988. Chemical ecology of the Heteroptera. Annual Review of Entomology, vol. 33, no. 1, pp. 211-238. http:// dx.doi.org/10.1146/annurev.en.33.010188.001235.

ALUJA, M., PÉREZ-STAPLES, D., SIVINSKI, J., SÁNCHEZ, A. and PIÑERO, J., 2008. Effects of male condition on fitness in two tropical tephritid flies with contrasting life histories. Animal Behaviour, vol. 76, no. 6, pp. 1997-2009. http://dx.doi. org/10.1016/j.anbehav.2008.08.020.

ARAÚJO, V.A., LINO-NETO, J., RAMALHO, F.S., ZANUNCIO, J.C. and SERRÃO, J.E., 2011. Ultrastructure and heteromorphism of spermatozoa in five species of bugs (Pentatomidae: Heteroptera). Micron, vol. 42, no. 6, pp. 560-567. http://dx.doi.org/10.1016/j. micron.2011.02.001. PMid:21376606.

BONDURIANSKY, R., 2001. The evolution of male mate choice in insects: a synthesis of ideas and evidence. Biological Reviews of the Cambridge Philosophical Society, vol. 76, no. 3, pp. 305-339. http://dx.doi.org/10.1017/S1464793101005693. PMid:11569787.

CAPONE, T.A., 1995. Mutual preference for large mates in green stink bugs, Acrosternum hilare (Hemiptera: Pentatomidae). Animal Behaviour, vol. 49, no. 5, pp. 1335-1344. http://dx.doi. org/10.1006/anbe.1995.0165.

CARROLL, S.P. and SALAMON, M.H., 1995. Variation in sexual selection on male body size within and between populations of the soapberry bug. Animal Behaviour, vol. 50, no. 6, pp. 1463-1474. http://dx.doi.org/10.1016/0003-3472(95)80003-4.

CARVALHO, R.S., VILELA, E.F., BORGES, M. and ZANUNCIO, J.C., 1995. Comportamento de casalamento do predador Podisus nigrispinus (Dallas) (Heteroptera: Pentatomidae: Asopinae). Anais da Sociedade Entomológica do Brasil, vol. 24, pp. 165-171.

COUDRON, T.A., SHELBY, K.S., ELLERSIECK, M.R., WINSTON, B.R. and POPHAM, H.J.R., 2011. Developmental response of the beneficial predator Podisus maculiventris to change in dietary ascorbic acid concentration. Entomologia Experimentalis et Applicata, vol. 139, no. 3, pp. 235-241. http:// dx.doi.org/10.1111/j.1570-7458.2011.01127.x.

CRESPI, B.J., 1989. Causes of assortative mating in arthropods. Animal Behaviour, vol. 38, no. 6, pp. 980-1000. http://dx.doi. org/10.1016/S0003-3472(89)80138-1.

DE CLERCQ, P. and DEGHEELE, D., 1992. Effects of mating status on body weight, oviposition, egg load, and predation in the predatory stinkbug Podisus maculiventris (Heteroptera: 
Pentatomidae). Annals of the Entomological Society of America, vol. 90, no. 2, pp. 121-127. http://dx.doi.org/10.1093/aesa/90.2.121.

DE CLERCQ, P., KEPPENS, G., ANTHONIS, G. and DEGHEELE, D., 1998. Laboratory rearing of the predatory stinkbug Podisus sagitta (Fab.) (Heteroptera: Pentatomidae). Mededelingen Faculteit Landbouwwetenschappen Rijksuniversiteit Gent, vol. 53, pp. 1213-1217.

DICKENS, J.C., 1999. Predator-prey interactions: Olfactory adaptations of generalist and specialist predators. Agricultural and Forest Entomology, vol. 1, no. 1, pp. 47-54. http://dx.doi. org/10.1046/j.1461-9563.1999.00007.x.

FORTES, P., MAGRO, S.R., PANIZZI, A.R. and PARRA, J.R.P., 2006. Development of a dry artificial diet for Nezara viridula (L.) and Euschistus heros (Fabricius) (Heteroptera: Pentatomidae). Neotropical Entomology, vol. 35, no. 5, pp. 567-572. http://dx.doi. org/10.1590/S1519-566X2006000500001. PMid:17144126.

FRANCO, K., JAUSET, A. and CASTAÑÉ, C., 2011. Monogamy and polygamy in two species of mirid bugs: a functional-based approach. Journal of Insect Physiology, vol. 57, no. 2, pp. 307-315. http://dx.doi.org/10.1016/j.jinsphys.2010.11.020. PMid:21130096.

HIBINO, Y., 1986. Female choice for male gregariousness in a stink bug, Megacopta punctissimum (Montandom) (Heteroptera, Plataspidae). Journal of Ethology, vol. 4, no. 2, pp. 91-95. http:// dx.doi.org/10.1007/BF02348110.

HINGLE, A., FOWLER, K. and POMIANKOWSKI, A., 2001. Size-dependent mate preference in the stalk-eyed fly Cyrtodiopsis dalmanni. Animal Behaviour, vol. 61, no. 3, pp. 589-595. http:// dx.doi.org/10.1006/anbe.2000.1613.

HOLTZ, A.M., ALMEIDA, G.A., FADINI, M.A.M., ZANUNCIO, J.C., ZANUNCIO, J.S. and ANDRADE, G.S., 2011. Phytophagy on eucalyptus plants increases the development and reproduction of the predator Podisus nigrispinus (Hemiptera: Pentatomidae). Acta Scientiarum. Agronomy, vol. 33, pp. 231-235.

JUSSELINO-FILHO, P., ZANUNCIO, J.C., FRAGOSO, D.B., SERRÃO, J.E. and LACERDA, M.C., 2003. Biology of Brontocoris tabidus (Heteroptera: Pentatomidae) fed with Musca domestica (Diptera: Muscidae) larvae. Brazilian Journal of Biology $=$ Revista Brasileira de Biologia, vol. 63, no. 3, pp. 463-468. http://dx.doi. org/10.1590/S1519-69842003000300012. PMid:14758705.

KRUPKE, C.H., BRUNNER, J.F. and JONES, V.P., 2008. Factors influencing mate choice in Euschistus conspersus Uhler (Heteroptera: Pentatomidae). Environmental Entomology, vol. 37, no. 1, pp. 192-197. http://dx.doi.org/10.1603/0046-225X(20 08)37[192:FIMCIE]2.0.CO;2. PMid:18348810.

LACERDA, M.C., FERREIRA, A.M.R.M., ZANUNCIO, T.V., ZANUNCIO, J.C., BERNARDINO, A.S. and ESPINDULA, M.C., 2004. Development and reproduction of Podisus distinctus (Heteroptera: Pentatomidae) fed on larva of Bombyx mori (Lepidoptera: Bombycidae). Brazilian Journal of Biology = Revista Brasileira de Biologia, vol. 64, no. 2, pp. 237-242. http:// dx.doi.org/10.1590/S1519-69842004000200008. PMid:15462296.

LEGASPI, J.C. and LEGASPI JUNIOR, B.C., 2004. Does a polyphagous predator prefer prey species that confer reproductive advantage? Case study of Podisus maculiventris. Environmental Entomology, vol. 33, no. 5, pp. 1401-1409. http://dx.doi. org/10.1603/0046-225X-33.5.1401.

LEGASPI, J.C., O’NEIL, R.J. and LEGASPI, B.C. Jr., 1996. Trade-offs in body weights, egg loads, and fat reserves of fieldcollected Podisus maculiventris (Heteroptera: Pentatomidae). Environmental Entomology, vol. 25, no. 1, pp. 155-164. http:// dx.doi.org/10.1093/ee/25.1.155.
LEMOS, W.P., RAMALHO, F.S., SERRÃO, J.E. and ZANUNCIO, J.C., 2003. Effects of diet on development of Podisus nigrispinus (Dallas) (Het., Pentatomidae), a predator of the cotton leafworm. Journal of Applied Entomology, vol. 127, no. 7, pp. 389-395. http://dx.doi.org/10.1046/j.1439-0418.2003.00765.x.

LEMOS, W.P., ZANUNCIO, J.C. and SERRÃO, J.E., 2005a. Attack behavior of Podisus rostralis (Heteroptera: Pentatomidae) adults on caterpillars of Bombyx mori (Lepidoptera: Bombycidae). Brazilian Archives of Biology and Technology, vol. 48, no. 6, pp. 975-981. http://dx.doi.org/10.1590/S1516-89132005000800014.

LEMOS, W.P., RAMALHO, F.S., SERRÃO, J.E. and ZANUNCIO, J.C., 2005b. Morphology of female reproductive tract of the predator Podisus nigrispinus (Dallas) (Heteroptera: Pentatomidae) fed on different diets. Brazilian Archives of Biology and Technology, vol. 48, no. 1, pp. 129-138. http://dx.doi.org/10.1590/S151689132005000100017.

LEMOS, W.P., SERRÃO, J.E., ZANUNCIO, J.C., LACERDA, M.C., ZANUNCIO, V.V. and RIBEIRO, R.C., 2009. Body weight and protein content in the haemolymph of females of the zoophytophagous predator Brontocoris tabidus (Heteroptera: Pentatomidae) with different diets and ages. Journal of Plant Diseases and Protection, vol. 116, no. 5, pp. 218-222. http:// dx.doi.org/10.1007/BF03356314.

LUNDGREN, J.G., 2011. Reproductive ecology of predaceous Heteroptera. Biological Control, vol. 59, no. 1, pp. 37-52. http:// dx.doi.org/10.1016/j.biocontrol.2011.02.009.

MCLAIN, D.K., 1980. Female choice and the adaptive significance of prolonged copulation in Nezara viridula. Journal of the Georgia Entomological Society, vol. 16, pp. 67-70.

MOHAGHEGH, J., DE CLERCQ, P. and TIRRY, L., 1998. Maternal age and egg weight affect offspring performance in the predatory stink bug Podisus nigrispinus. BioControl, vol. 43, no. 2, pp. 163-174. http://dx.doi.org/10.1023/A:1009902710191.

MOHAGHEGH, J., DE CLERCQ, P. and TIRRY, L., 1999. Effects of rearing history and geographical origin on reproduction and body size of the predator Podisus nigrispinus (Heteroptera: Pentatomidae). European Journal of Entomology, vol. 96, pp. 69-72.

MORAES, M.C.B., PAREJA, M., LAUMANN, R.A. and BORGES, M., 2008. The chemical volatiles (semiochemicals) produced by Neotropical stink bugs (Hemiptera: Pentatomidae). Neotropical Entomology, vol. 37, no. 5, pp. 489-505. http://dx.doi.org/10.1590/ S1519-566X2008000500001. PMid:19061033.

O'NEIL, R.J., NAGARAJAN, K., WIEDENMANN, R.N. and LEGASPI, J.C., 1996. A simulation model of Podisus maculiventris (Say) (Heteroptera: Pentatomidae) and mexican bean beetle, Epilachna varivestis (Mulsant) (Coleoptera: Coccinellidae), population dynamics in soybean, Glycine $\max ($ L.). Biological Control, vol. 6, no. 3, pp. 330-339. http://dx.doi.org/10.1006/ bcon.1996.0042.

OLIVEIRA, I., ZANUNCIO, J.C., SERRÃO, J.E., ZANUNCIO, T.V., PINON, T.B.M. and FIALHO, M.C.Q., 2005. Effect of female weight on reproductive potential of the predator Brontocoris tabidus (Signoret, 1852) (Heteroptera: Pentatomidae). Brazilian Archives of Biology and Technology, vol. 48, no. 2, pp. 295-301. http://dx.doi.org/10.1590/S1516-89132005000200017.

PEREIRA, A.I.A., RAMALHO, F.S., BANDEIRA, C.M., MALAQUIAS, J.B. and ZANUNCIO, J.C., 2009. Age-dependent fecundity of Podisus nigrispinus (Dallas) (Heteroptera: Pentatomidae) with sub lethal doses of Gammacyhalothrin. Brazilian Archives of Biology and Technology, vol. 52, no. 5, pp. 1157-1166. http:// dx.doi.org/10.1590/S1516-89132009000500013. 
PIRES, E.M., PINTO, R., LACERDA, M.C., ZANUNCIO, J.C. and FIALHO, M.C.Q., 2006. Potencial reprodutivo horário do predador de lagartas desfolhadoras do eucalipto: Podisus nigrispinus (Heteroptera: Pentatomidae). Revista Árvore, vol. 30, no. 6, pp. 1039-1044. http://dx.doi.org/10.1590/S0100-67622006000600020.

PIRES, E.M., ZANUNCIO, J.C. and SERRÃO, J.E., 2011. Cannibalism of Brontocoris tabidus and Podisus nigrispinus during periods of pre-release without food or fed with Eucalyptus cloeziana plants. Phytoparasitica, vol. 39, no. 1, pp. 27-34. http:// dx.doi.org/10.1007/s12600-010-0132-6.

RAMALHO, F.S., MEZZOMO, J., LEMOS, W.P., BANDEIRA, C.M., MALAQUIAS, J.B., SILVA, J.P.S., LEITE, G.L.D. and ZANUNCIO, J.C., 2008. Reproductive strategy of Podisus nigrispinus females under different feeding intervals. Phytoparasitica, vol. 36, no. 1, pp. 30-37. http://dx.doi.org/10.1007/BF02980745.

RIBEIRO JUNIOR, J.I. and MELO, A.L.P., 2008. Guia prático para utilização do SAEG. Viçosa: Editora UFV. 288 p.

RODRIGUES, A.R.S., SERRÃO, J.E., TEIXEIRA, V.W., TORRES, J.B. and TEIXEIRA, A.A., 2008. Spermatogenesis, changes in reproductive structures, and time constraint associated with insemination in Podisus nigrispinus. Journal of Insect Physiology, vol. 54, no. 12, pp. 1543-1551. http://dx.doi.org/10.1016/j. jinsphys.2008.09.003. PMid:18845152.

RODRIGUES, A.R.S., TORRES, J.B., SIQUEIRA, H.A.A. and TEIXEIRA, V.W., 2009. Podisus nigrispinus requer cópulas longas para o sucesso reprodutivo. Neotropical Entomology, vol. 38, no. 6, pp. 746-753. http://dx.doi.org/10.1590/S1519566X2009000600007. PMid:20098920.

SANTOS, T.M. and BOIÇA JUNIOR, A.L., 2002. Biological aspects and predatory capacity of Podisus nigrispinus (Dallas) (Hemiptera: Pentatomidae) fed on Alabama argillacea (Hübner) (Lepidoptera: Noctuidae) reared on cotton genotypes. Scientia Agricola, vol. 59, no. 4, pp. 671-675. http://dx.doi.org/10.1590/ S0103-90162002000400008.

SCHÄFER, M.A., MISOF, B. and UHL, G., 2008. Effects of body size of both sexes and female mating history on male mating behaviour and paternity success in a spider. Animal Behaviour, vol. 76, no. 1, pp. 75-86. http://dx.doi.org/10.1016/j. anbehav.2008.01.011.

SCRIBER, J.M. and SLANSKY JUNIOR, F., 1981. The nutritional ecology of immature insects. Annual Review of Entomology, vol. 26 , no. 1 , pp. 183-211. http://dx.doi.org/10.1146/annurev. en.26.010181.001151

SHAPIRO, J.P. and LEGASPI, J.C., 2006. Assessing biochemical fitness of predator Podisus maculiventris (Heteroptera: Pentatomidae) in relation to food quality: effects of five species of prey. Annals of the Entomological Society of America, vol. 99, no. 2, pp. 321326. http://dx.doi.org/10.1603/0013-8746(2006)099[0321:ABF OPP]2.0.CO;2.

SHAPIRO, J.P., WASSERMAN, H.A., GREANY, P.D. and NATION, J.L., 2000. Vitellin and vitellogenin in the soldier bug, Podisus maculiventris: Identification with monoclonal antibodies and reproductive response to diet. Archives of Insect Biochemistry and Physiology, vol. 44, no. 3, pp. 130-135. http://dx.doi.org/10.1002/1520-6327(200007)44:3<130::AIDARCH4>3.0.CO;2-B. PMid:10897094.
TORRES, J.B., ZANUNCIO, J.C. and MOURA, M.A., 2006. The predatory stinkbug Podisus nigrispinus: biology, ecology and augmentative releases for lepidoperan larval control in Eucalyptus forests in Brazil. CAB Reviews: Perspective in Agriculture Veterinary Science Nutrition and Natural Resources, vol. 15 , pp. 1-18.

TOSTOWARYK, W., 1971. Life history and behavior of Podisus modestus (Hemiptera: Pentatomidae) in boreal forest in Quebec. Canadian Entomologist, vol. 103, no. 05, pp. 662-674. http:// dx.doi.org/10.4039/Ent103662-5.

ZANUNCIO, J.C., DIDONET, J., SANTOS, G.P. and ZANUNCIO, T.V., 1992. Determinação da idade ideal para acasalamento de fêmeas de Podisus connexivus Bergroth, 1891 (Hemiptera: Pentatomidae) visando uma criação massal. Revista Árvore, vol. 16, pp. 362-367.

ZANUNCIO, J.C., MOLINA-RUGAMA, A.J., SERRÃO, J.E. and PRATISSOLI, D., 2001. Nymphal development and reproduction of Podisus nigrispinus (Heteroptera: Pentatomidae) fed with combinations of Tenebrio molitor (Coleoptera: Teneobridae) pupae and Musca domestica (Diptera: Muscidae) larvae. Biocontrol Science and Technology, vol. 11, no. 3, pp. 331-337. http://dx.doi. org/10.1080/09583150120055736.

ZANUNCIO, J.C., GUEDES, R.N.C., OLIVEIRA, H.N. and ZANUNCIO, T.V., 2002a. Uma década de estudos com percevejos predadores: conquistas e desafios. In: J.R.P. PARRA, P.S.M. BOTELHO, B.S. CORREAA-FERREIRA and J.M.S. BENTO, eds. Controle biológico no Brasil: parasitóides e predadores. São Paulo: Manole, pp. 495-509.

ZANUNCIO, J.C., MOLINA-RUGAMA, A.J., SANTOS, G.P. and RAMALHO, F.S., 2002b. Effect of body weight on fecundity and longevity of the stinkbug predator Podisus rostralis. Pesquisa Agropecuaria Brasileira, vol. 37, no. 9, pp. 1225-1230. http:// dx.doi.org/10.1590/S0100-204X2002000900004.

ZANUNCIO, J.C., LACERDA, M.C., ZANUNCIO JÚNIOR, J.S., ZANUNCIO, T.V., SILVA, A.M.C. and ESPINDULA, M.C., 2004. Fertility table and rate of population growth of the predator Supputius cinctceps (Heteroptera: Pentatomidae) on one plant of Eucalyptus cloeziana in the field. Annals of Applied Biology, vol. 144, no. 3, pp. 357-361. http://dx.doi. org/10.1111/j.1744-7348.2004.tb00351.x.

ZANUNCIO, J.C., FERREIRA, A.M.R.M., TAVARES, W.S., TORRES, J.B., SERRÃO, J.E. and ZANUNCIO, T.V., 2011. Rearing the predator Brontocoris tabidus (Heteroptera: Pentatomidae) with Tenebrio molitor (Coleoptera: Tenebrionidae) pupa on Eucalyptus grandis in the field. American Journal of Plant Sciences, vol. 2, no. 03, pp. 449-456. http://dx.doi.org/10.4236/ajps.2011.23052.

ZANUNCIO, T.V., FREITAS, F.A., TAVARES, W.S., MENEZES, C.W.G., SERRÃO, J.E. and ZANUNCIO, J.C., 2012. Podisus nigrispinus (Heteroptera: Pentatomidae) and IAC-24 soybean cultivar are compatible. Sustainable Agriculture Research, vol. 1, no. 2, pp. 41-50. http://dx.doi.org/10.5539/sar.v1n2p41.

ZUNIC, A., COKL, A., DOBERLET, M.V. and MILLAR, J.G., 2008. Communication with signals produced by abdominal vibration, tremulation, and percussion in Podisus maculiventris (Heteroptera: Pentatomidae). Annals of the Entomological Society of America, vol. 101, no. 6, pp. 1169-1178. http://dx.doi. org/10.1603/0013-8746-101.6.1169. 